\title{
Australia backs innovation, shuns telescope
}

Sydney. In a move designed to stimulate both science and technological innovation in Australia, the prime minister, Paul Keating, last week announced the launch of several new national and international science facilities and projects.

These include Australia's first dedicated centre for genome research, and another for mass screening of proteins. But Australian and European astronomers were disappointed that an expected contribution to the European Southern Observatory's Very Large Telescope (VLT), currently under construction in Chile, did not materialize.

Keating made what he called an "innovation statement" at a business conference in Melbourne. Its main contents, however, were completed several months ago, and their presentation had been timed to give maximum benefit to the ruling Labor Party's general election campaign early next year.

In the intervening period, several significant changes were made. Last year, for example, the government called for proposals for several 'major national research facilities'. More than 60 applications were received, including some projects involving facilities overseas, and these were reduced to 16 about six months ago.

At that time, it was widely anticipated that a proposal to contribute $\mathrm{A} \$ 28$ million (US\$20.35 million) to the VLT, to include the construction of low-noise reccivers built in Australia, would be selected from the short-list .

\section{Government backs proteome proposal}

Sydney. A year ago, a proposal by Keith Williams of Macquarie University in Sydney, New South Wales, was little more than a dream. But good fortune - and the ill-fortune of astronomers - has given him time to demonstrate that his idea of mass screening and sequencing proteins, much like the rapid sequencing of DNA, is both feasible and fast enough to provide an alternative approach to the molecular analysis of whole organisms.

The term 'proteome' was coined by Marc Wilkins, a former PhD student of Keith Williams, to describe an entire organism's protein complement. Williams's idea is to screen and determine all the proteins produced by the DNA of an organism, rather than using the more conventional approach of sequencing DNA in order to determine the genes that produce proteins.

The protein approach provides important additional information, as, after their translation from DNA, many proteins are modified by sugars and phosphates. Such changes can have
But the telescope proposal has been dropped for several reasons. One is that it would have consumed almost half of the A $\$ 60$ million set aside for the 'national' facilities, and would have severely limited the number of others that could be funded.

The more important considerations, however, appear to have been political. Australia's politicians are keen to develop economic, trade and science links with countries in the Asia-Pacific region, following a successful meeting of the Asia-Pacific Economic Forum (APEC) in Osaka, Japan, last month.

Both the Australian cabinet and the prime minister are said to have considered the word 'European' to be unattractive in this political climate. With a general election looming, many Australian scientists suspect they were also keen to maximize the overall number of national facilities, so that one major facility could be given to every major city in Australia, namely Sydney, Canberra, Mclbourne, Brisbane, Perth, Hobart and Adelaide.

The seven facilities chosen, with a total funding of $\mathrm{A} \$ 62.4$ million, include a new genome research facility with 'nodes' at the University of Queensland in Brisbane and

profound effects on the biological function of proteins.

Until very recently, the technology required for rapid analysis of proteins lagged far behind that used for DNA analysis. But working with companies such as Beckman Australia and GBC Scientific Instruments (formerly part of $\mathrm{ICl}$ Australia), Williams's laboratory has developed many new machines for the rapid analysis of proteins, using a hierarchical approach progressing from the highest throughput and cheapest technology to the most expensive and timeconsuming, depending on how much information already exists about a given protein.

In addition, his laboratory can handle milligram quantities of samples on twodimensional electrophoresis gels that yield individual spots of pure protein of sufficient quantity for analysis. He claims to be able already to screen a hundred proteins a week, and that the new facility will screen a hundred a day at $A \$ 2$ a protein. the Walter and Eliza Hall Institute of Medical Research and Royal Melbourne Hospital in Melbourne. This facility will carry out major gene sequencing and mapping projects, and will received Aus $\$ 10$ million.

A further A $\$ 7$ million will be spent on the 'Proteome' analysis centre at Macquarie University in Sydney for rapid mass-screening of proteins (see below).

A sum of $\mathrm{A} \$ 12.2$ million is to be spent on a synchrotron research programme, which will provide Australian scientists with access to an upgraded beamline at Japan's Photon

Factory in Tsukuba Science City, and a new beamline at the Advanced Photon Source at Argonne National Laboratory in the United States. This also includes funds for a feasibility study of an Australian synchrotron.

Other facilities include:

- the Airborne Research Australia Facility, at South Australia's Flinders University, which will carry out atmospheric and meteorological research, including studies of the ozone layer over Australia;

- a Plasma Fusion Research Facility, an upgrade of the Heliac Plasma Facility at the Australian National University (ANU) in Canberra, where the 'stellarator' approach to fusion is being developed; and

- a National Seismic Imaging Resource for generating three-dimensional images of the Earth to depths of more than $1,000 \mathrm{~km}$, which will have facilities and equipment based at the Australian Geodynamics Cooperative Research Centre in Perth, the ANU's Research School of Earth Sciences and the Australian Geological Survey.

As something of a consolation prize for astronomers, the Australia Telescope will get $\mathrm{A} \$ 11$ million for an upgrade - $\mathrm{A} \$ 1.3$ million more than it had requested. These funds will be used to extend the telescope's wavelength range and angular resolution by a factor of ten, and will involve all the telescope's sites in New South Wales.

The extra money will also be used to convert the Telstra antenna in Ceduna, South Australia, and the University of Tasmania's radio telescope at Hobart to create a six-station Australian network of antennae for very-long-baseline studies.

Astronomers hope that they may be able to salvage a few million dollars from the larger-than-expected budget for the upgrade so they can contribute something to the European Southern Observatory in Chile. But this would still be an order of magnitude less than originally hoped for. 